\title{
Microbial parameters as indicators of mariculture impact on the marine environment
}

\author{
G. Caruso \& G. Zappalà \\ Istituto per l'Ambiente Marino Costiero (IAMC), \\ National Research Council, Italy
}

\begin{abstract}
Microbial abundance and extracellular activity rates (leucine aminopeptidase, LAP, beta-glucosidase, $\beta$-GLU, and alkaline phosphatase, AP) were studied in water and sediment samples for two years in three Sicilian mariculture sites. Microbial activities were measured with specific fluorogenic substrates; heterotrophic culturable bacteria (CFU) were counted on Marine agar plates. The amount of particulate organic matter (POM) and its composition in terms of bio-polymeric fractions (proteins, carbohydrates, lipids) were also monitored as indicators of trophic conditions. Cage sites were sampled before and after the set up of each off-shore mariculture plant, and compared to "control" sites. The study aimed at monitoring the impact caused by fish farming activities on the marine environment and at assessing the suitability of these microbial parameters as indirect indicators of organic pollution.

Significant variations occurred both in microbial activity rates and in abundances at cage stations. Compared with the trophic parameters, the microbial parameters showed a more direct response to environmental perturbation due to fish farming. This suggested their use as indicators in assessing fish farming impact on both the pelagic and benthic compartments.
\end{abstract}

Keywords: mariculture, environmental impact, microbial parameters, extracellular enzyme activity, heterotrophic culturable bacteria, water, sediment.

\section{Introduction}

The increase in mariculture recorded in recent years has led to a consistent number of studies about the potential impact of rearing activities on the marine environment. The massive inputs of organic wastes (i.e. excretes, faeces, feed 
wastes and medicinal substances) are the main cause of pollution occurring both in the pelagic and benthic compartments $[1,2]$. Only a few studies have focused on the consequences of aquaculture on the functioning of the ecosystems [3-6] and on the need of new descriptors of environmental impact [7, 8]. Microbial decomposition of organic polymers through extracellular enzymes plays a major role in the turnover of organic matter in aquatic ecosystems [9]. It is well known that microorganisms are able to respond to organic matter enrichment and to the variation of the trophic conditions by modulating their activity rates [10, 11]. Previous researches $[5,6,12,13]$ have pointed out that both total prokaryotic abundance and enzyme activity rates undergo significant changes in association with mariculture or aquaculture practices.

A multidisciplinary study was performed to investigate the impact of offshore mariculture in three Mediterranean sites (Castellammare Gulf, Capo d'Orlando and Portopalo), where experimental plants using off-shore cages were set up. A two-year investigation was carried out to quantify the impact of fish farming on the marine environment, both at pelagic and benthic levels. Particularly, some extracellular enzyme activities (leucine aminopeptidase, LAP, beta-glucosidase, $\beta$-GLU, alkaline phosphatase, AP), involved in the decomposition of proteins, polysaccharides and organic phosphates respectively, were estimated, together with the heterotrophic bacterial density and the content of particulate organic matter (POM) and of its biopolymeric fraction (proteins, carbohydrates and lipids). The research aimed to detect possible variations in the distribution of the examined parameters due to productive activities, and to evaluate the suitability of the microbial parameters (abundance and activity) as indicators of fish farming impact, in comparison with the parameters conventionally related to the trophic status, such as POM and organic biopolymers.

\section{Materials and methods}

\subsection{Study areas and experimental design}

The study sites were three marine areas used for mariculture. In two of them, Castellammare Gulf (site A) and Capo d'Orlando (site B), located along the North-Western and North-Eastern Tyrrhenian coast respectively, two experimental mariculture plants were set up, while in the third site (Portopalo, site C), located along the South-Western coast of Sicily, off-shore fish farming was performed using a previously-established productive plant (Sicily Fish Farm). The microbiological controls were performed on both seawater $(0.5 \mathrm{~m}$ depth) and sediment (surface layer, 0-1 cm) samples. Four stations ("cage stations"), located near the rearing structures, were sampled per each of the sites $\mathrm{A}$ and $\mathrm{B}$; two other stations, located $1 \mathrm{Km}$ away from the cages, were used as "control stations". Four samplings were performed, two covering the period of cage set up, in 2004 (site A: May and June; site B: May and July), and the remaining two one year later, when the mariculture plant was already in an active productive phase. At site C only two samplings were carried out, both in July 2004 and 2005 (pre-impact and post-impact periods, respectively). 


\subsection{Studied parameters}

\subsubsection{Microbial parameters}

Extracellular enzyme activities were determined using specific fluorogenic substrates. Water sub-samples $(10 \mathrm{ml})$ were added with increasing amounts of the substrates L-leucine-7amido-4-methyl-coumarin hydrochloride (Leu-MCA), 4-methylumbelliferyl (MUF)- $\beta$-glucoside and MUF-phosphate for LAP, $\beta$-GLU and AP, respectively [14]. Concentrations ranging from 0.1 to $200 \mu \mathrm{M}$ were used for LAP and AP, while for $\beta$-GLU slightly lower concentrations (0.1-100 $\mu \mathrm{M})$ were applied; saturation was generally reached when a final concentration of 200 $\mu \mathrm{M}$ was used. Measurements were performed with a Turner TD700 fluorimeter, equipped with specific filters (excitation/emission wavelengths: $380 / 440 \mathrm{~nm}$ for LAP and 365/455 nm for AP and $\beta$-GLU) after 3 hours of incubation at "in situ" $\left( \pm 1^{\circ} \mathrm{C}\right.$ ) temperature. Known concentrations (range: 20-80 $\mu \mathrm{M}$ ) of methylcoumarine (MCA) and methylumbelliferone (MUF), were used as the standards for Leu-MCA and MUF- $\beta$-glucoside and MUF-phosphate respectively. The maximum velocity $\left(\mathrm{V}_{\max }\right)$ of hydrolysis of the substrate was calculated through the Lineweaver-Burke transformation of each substrate concentration plotted versus the corresponding velocity of hydrolysis and reported as $\mathrm{nM} \mathrm{h}^{-1}$.

Sediment samples were re-suspended and diluted in sterile seawater, in a 1:10 (weight: volume) ratio. $\mathrm{V}_{\max }$ was reported as $\mu \mathrm{M} \mathrm{h}^{-1}$ and normalised to the dry weight of sediment.

Heterotrophic culturable bacteria (CFU) were counted by culture method on Marine agar 2216 (Difco) plates incubated at $22^{\circ} \mathrm{C}$ for 7 days. They were reported as the number of Colony Forming Units (CFU) per $\mathrm{ml}$ or $\mathrm{g}$.

\subsubsection{Biochemical parameters (POM and its biopolymeric fractions)}

POM concentration was estimated after filtration of water samples on a Whatman $\mathrm{GF} / \mathrm{F}$ membrane, and filters were processed at $980^{\circ} \mathrm{C}$ in a PerkinElmer CHN-Autoanalyzer 2400, using acetanilide as the standard [15]. The biopolymeric fraction [proteins (PRT), carbohydrates (CHO), and lipids (LIP)] was also determined [16-18].

\subsection{Statistical analysis}

Analysis of variance (ANOVA) was performed to evaluate the statistical significance of "time" (pre-impact versus post-impact periods) or "space" factors (cage versus control stations). Prior to analysis, logarithmic data transformation was carried out to attain their normal distribution. Pearson correlation coefficient $r$ between microbial and biochemical parameters was also calculated.

\section{Results}

The mean values of enzyme activities and CFU obtained at each examined site are reported in Table 1, separately for water and sediment compartments. 


\subsection{Water}

Mean temperature values ranged from 17.80 to $26.16{ }^{\circ} \mathrm{C}, 26.03$ to $27.02{ }^{\circ} \mathrm{C}$, 18.70 to $20.99{ }^{\circ} \mathrm{C}$, in Castellammare Gulf, Capo d'Orlando and Sciacca, respectively; at the same sites, mean salinity values ranged from 36.24 to 37.72 , 37.86 to $38.00,36.35$ to 37.80 , respectively. Fig. 1 shows the mean enzyme activity and CFU values obtained in the waters of the sites $\mathrm{A}, \mathrm{B}$ and $\mathrm{C}$, at the cage and control stations. Fig. 2 shows the mean concentrations of both POM and its biopolymeric fractions measured at the three sites A, B, C.

The patterns of enzyme activities and POM evidenced a large variability depending on the studied site. At site A both the enzyme activity rates and CFU showed, on average, higher values at cage stations compared to control ones, although significant differences between the stations were found for LAP ( $\mathrm{F}=$ 5.98, $\mathrm{P}<0.05)$ and $\mathrm{CFU}(\mathrm{F}=11.37, \mathrm{P}<0.01)$ only. Comparing pre- with postimpact periods, significant changes were recorded in the mean values of LAP and AP, which were both particularly active at this site, and increased at cage stations about 38 and 23 times compared to their pre-impact values $(\mathrm{F}=7.12$, 19.86, $\mathrm{P}<0.01$, respectively).

Mean $\beta$-GLU and CFU values also increased significantly over time at cage stations $(\mathrm{F}=8.34,7.87, \mathrm{P}<0.01$, respectively $)$, confirming the rapid responsiveness to organic inputs of both microbial metabolism and abundance.

Mean POM values showed the abundance of organic matter at site A, which was higher, although not significantly, at control stations than at cage ones. A similar distribution was observed for the biopolymeric fraction. Peaks in the values of biochemical parameters occurred during spring; a significant interannual reduction was observed from pre-impact to post-impact periods $(\mathrm{F}=$ $10.87,6.23,6.36, \mathrm{P}<0.01$, for $\mathrm{POM}$, PRT and $\mathrm{CHO}$ ). This result could be related to the increase of both LAP $(\mathrm{r}=-0.82, \mathrm{P}<0.01, \mathrm{n}=8$ with POM) and $\beta$-GLU $(\mathrm{r}=$ $-0.63, \mathrm{P}<0.05, \mathrm{n}=8$ with $\mathrm{POM}$ ), suggesting that the microbial community was actively metabolising the available organic matter.

At site B (Fig. 1), mean enzyme activities and CFU were lower than those found at site A throughout the experimental period. A different behaviour was observed for $\beta$-GLU, whose activity levels were high at this site. Enzyme activity values were generally higher at cage stations than at control ones, with significant differences detected both for LAP and CFU $(F=6.31$ and 5.64, $\mathrm{P}<0.05$, respectively). ANOVA confirmed a significant increase over years for LAP, AP, CFU ( $\mathrm{F}=4.83,5.04,4.50, \mathrm{P}<0.05$, respectively), and mostly for $\beta$ GLU $(F=24.83, P<0.01)$, suggestive of the cage impact on the environment.

Concerning the biochemical parameters, lower mean POM concentrations were recorded at site $\mathrm{B}$ compared to site $\mathrm{A}$, both at cage and control stations. This site showed the minimum PRT and $\mathrm{CHO}$ concentrations at the control stations.

At cage stations, mean values of POM increased over time, particularly PRT, as demonstrated by ANOVA $(\mathrm{F}=6.83, \mathrm{P}<0.01$ between pre- and post-impact periods), suggesting the water enrichment due to the release of organic wastes; 

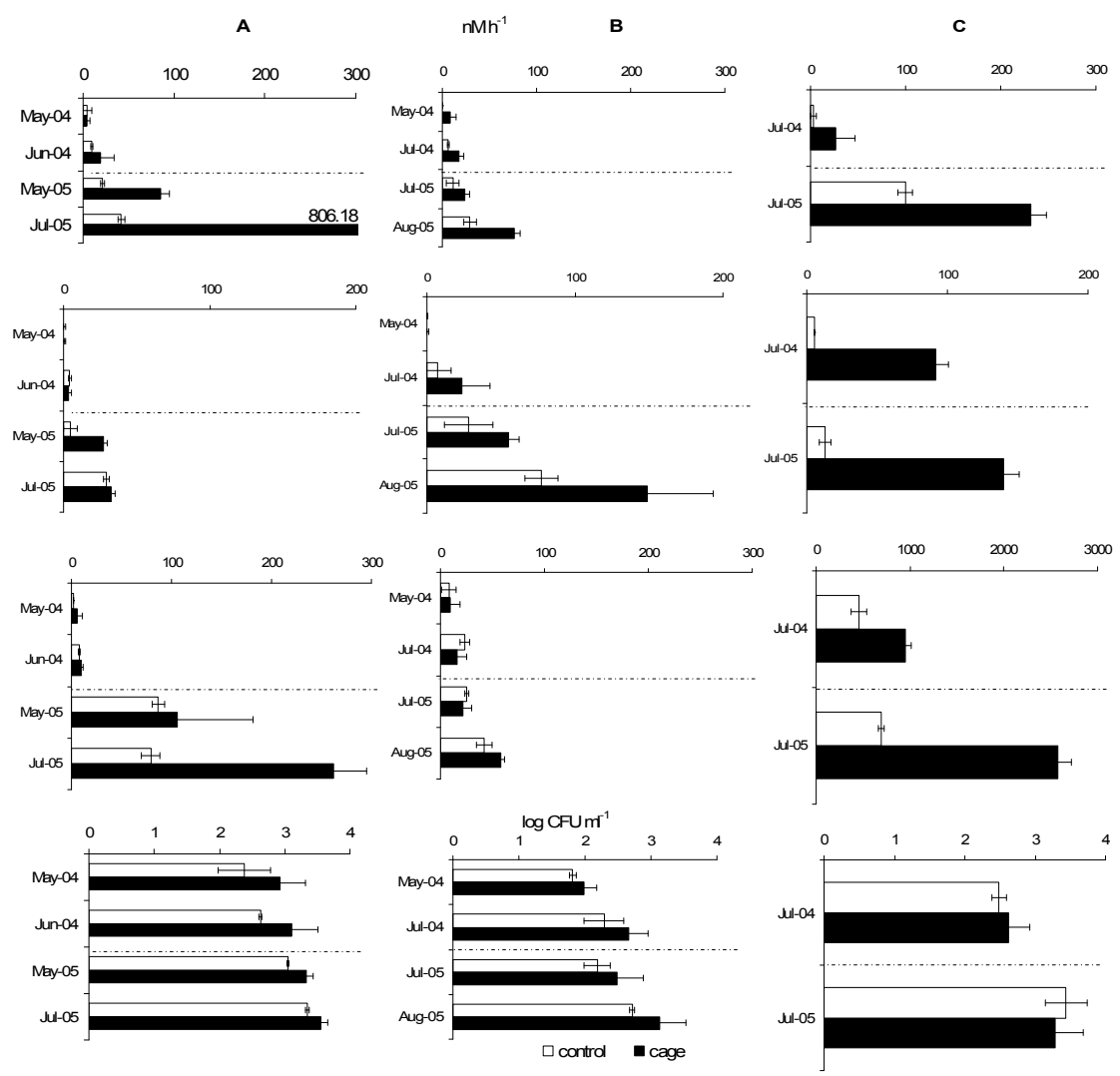

Figure 1: Water. Mean values \pm s.d. of enzyme activity rates and heterotrophic bacteria obtained over time at cage and control stations of sites A, (Castellammare Gulf), B (Capo d'Orlando) and $\mathrm{C}$ (Sciacca). First line: LAP; second line: $\beta$-GLU; third line: AP; fourth line: CFU. Dotted lines separate the pre-impact period from the post-impact one.

conversely, mean $\mathrm{CHO}$ and LIP values remained almost unchanged over time (Fig. 2).

Site $\mathrm{C}$ was characterised by peaks of both AP and $\beta$-GLU and by LAP values which were intermediate between those detected at sites A and B. Similarly to other sites, both enzyme activities and CFU values were higher at cage stations, than at control ones. Only AP values displayed statistically significant spatial differences $(\mathrm{F}=8.24, \mathrm{P}<0.05)$, while an inter-annual increase was observed for LAP, AP and CFU values $(\mathrm{F}=15.23, \mathrm{P}<0.01 ; 6.34, \mathrm{P}<0.05 ; 16.49, \mathrm{P}<0.01$ respectively). 


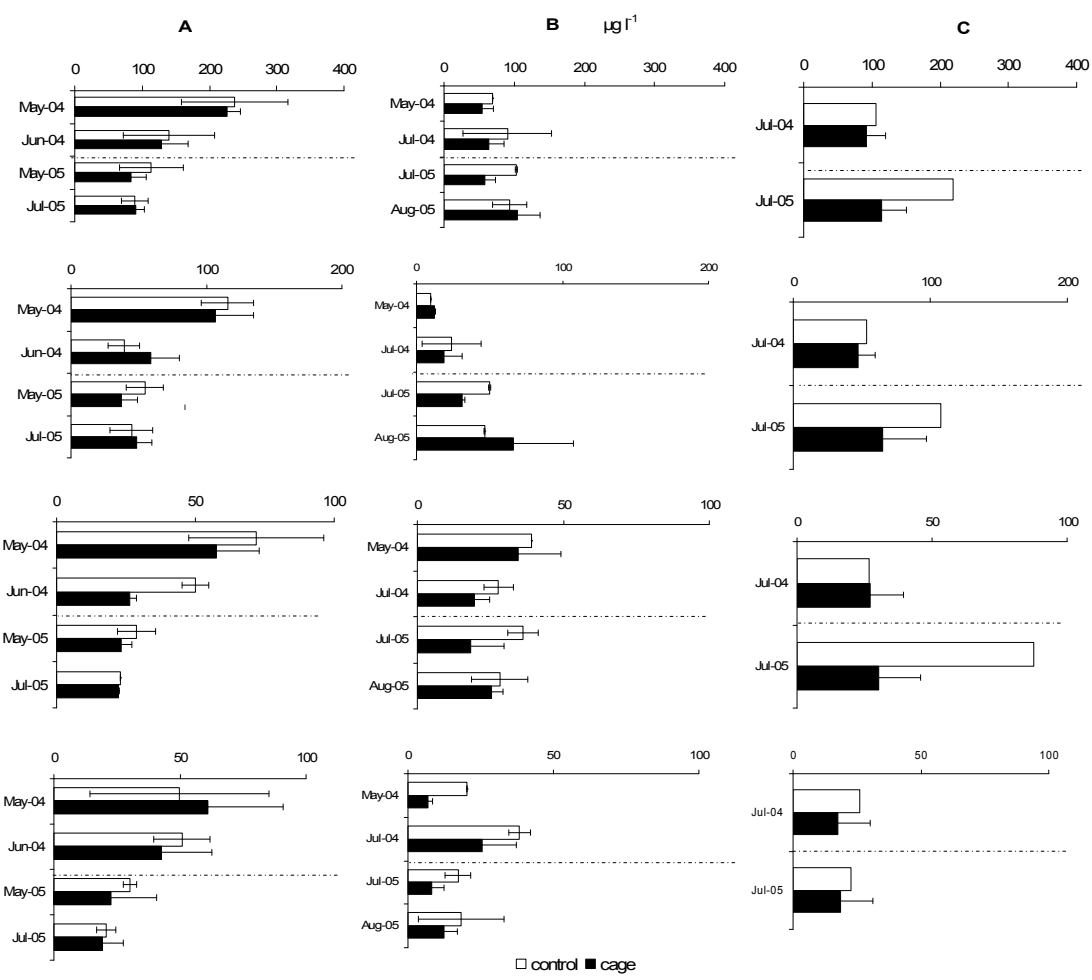

Figure 2: Water. Mean values \pm s.d. of POM and its biopolymeric fractions. First line: POM; second line: PRT; third line: $\mathrm{CHO}$; fourth line: LIP. Dotted lines separate the pre-impact period from the postimpact one.

Regarding the biochemical parameters (Fig. 2), POM concentrations in site $\mathrm{C}$ were intermediate between those recorded at sites A and B. At cage stations, both PRT and CHO reached their maximum values compared to those found in the other sites. Spatial and temporal variations were not significant.

\subsection{Sediment}

Fig. 3 shows the mean enzyme activity values and CFU obtained in the sediments of the sites A, B and C, at cage and control stations, while the mean concentrations of POM and biopolymeric fractions at the same sites is illustrated in Fig. 4. In sediments, mean enzyme activity values were, on average, three orders of magnitude higher than those found in waters. Particularly, site A was characterised by high AP, which showed activity values higher at cage stations compared to control ones, although no significant spatial differences were observed (Table 1). A similar result was found for LAP $(\mathrm{F}=26.77, \mathrm{P}<0.01$, cage vs. control) and CFU (Table 1). A significant increase of both AP and CFU 
values between pre-impact and post-impact periods was recorded $(\mathrm{F}=9.31$, $\mathrm{P}<0.01,3.31, \mathrm{P}<0.05$, respectively).

POM concentrations measured at site A were higher at cage stations, perhaps due to the low hydrodynamism and low LAP and $\beta$-GLU activity rates of this site, which led to the sinking of organic matter in the sediment underneath the cages. At these latter, POM and its biopolymeric fractions (PRT, CHO, LIP) reached values of $3025.03 \mu \mathrm{g} \mathrm{g}^{-1}, 2366.99 \mu \mathrm{g} \mathrm{g}^{-1}, 482.13 \mu \mathrm{g} \mathrm{g}^{-1}$, and $204.74 \mu \mathrm{g}$ $\mathrm{g}^{-1}$, respectively.

All the biochemical parameters showed at cage stations values significantly higher than those found at control ones $(\mathrm{F}=12.23, \mathrm{P}<0.01,6.26, \mathrm{P}<0.05,11.29$, $10.71, \mathrm{P}<0.01$, for POM, PRT, CHO and LIP, respectively). No significant interannual variations were observed by ANOVA.

At site B LAP and AP reached activity values which were about one order of magnitude higher than those measured at the site A. At the cage stations, both microbial activities and CFU were always higher than those measured at control
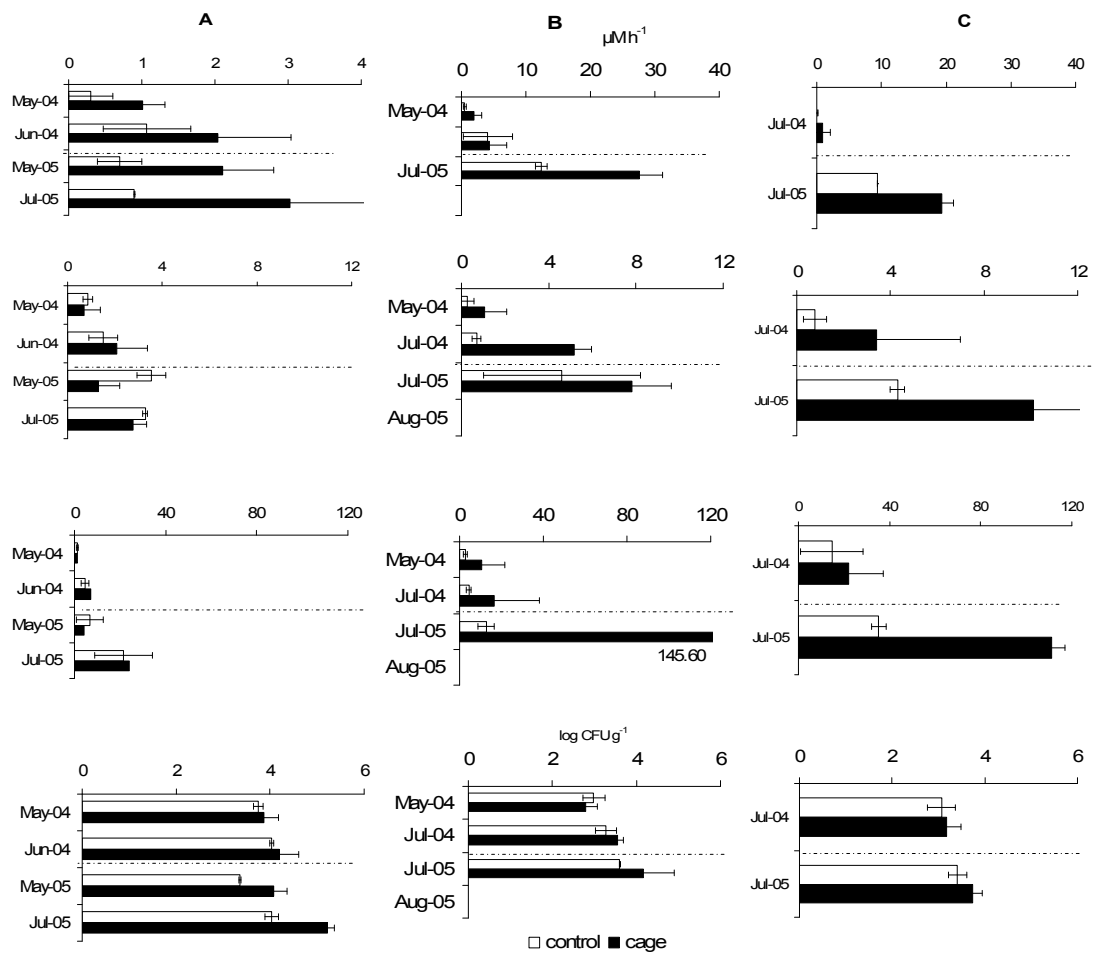

Figure 3: Sediment. Mean values \pm s.d. of enzyme activity rates and heterotrophic bacteria obtained over time at cage and control stations of sites A, B and C. First line: LAP; second line: $\beta-G L U$; third line: AP; fourth line: CFU. Dotted lines separate the preimpact period from the post-impact one. 


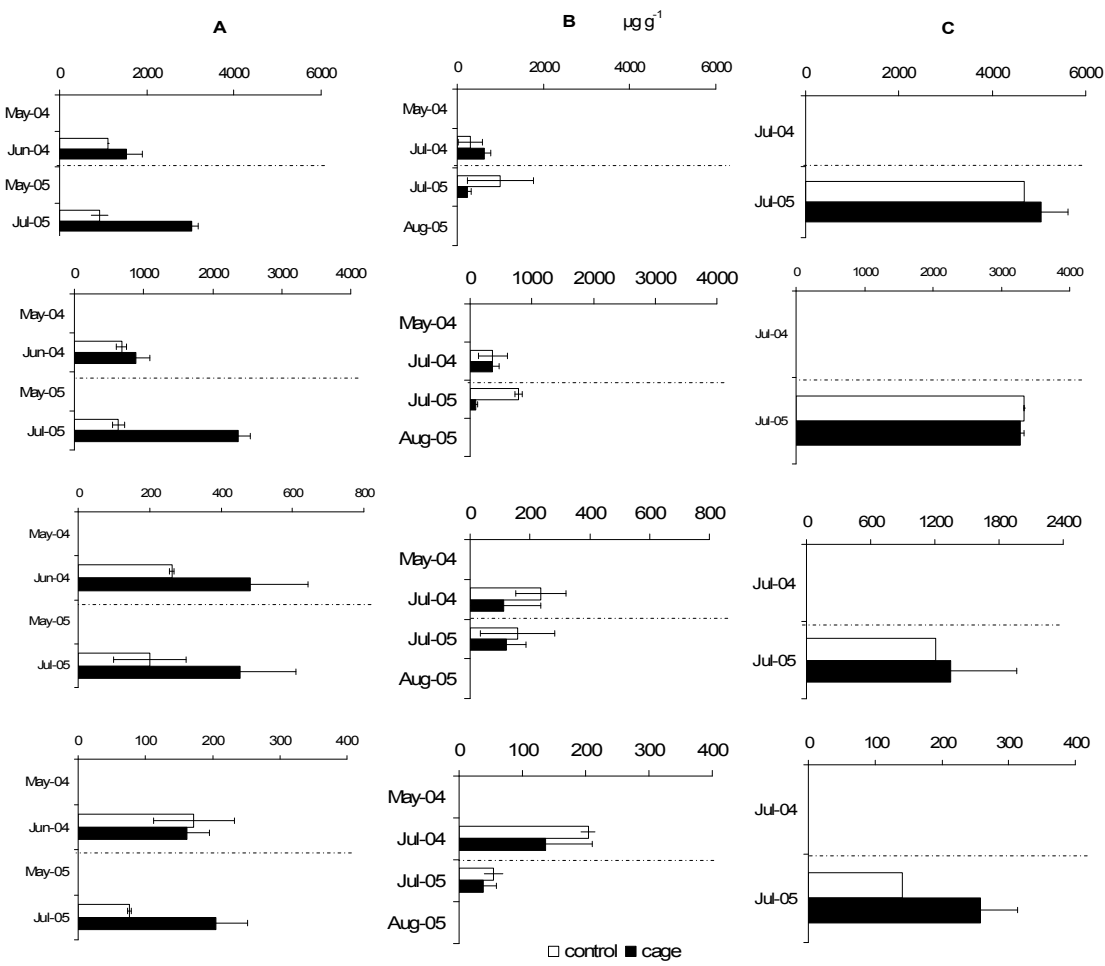

Figure 4: Sediment. Mean values \pm s.d. of POM and its biopolymeric fractions. First line: POM; second line: PRT; third line: $\mathrm{CHO}$; fourth line: LIP. Dotted lines separate the pre-impact period from the post-impact one.

stations; spatial significant differences were, however, recorded for $\beta$-GLU only $(\mathrm{F}=9.40, \mathrm{P}<0.01)$. Conversely, significant variations over time were observed for LAP, $\beta$-GLU and CFU ( $\mathrm{F}=10.79,7.82,8.08, \mathrm{P}<0.01$, respectively).

Both POM and its biopolymeric fractions displayed averaged concentrations 2 or 3 times (for CHO or PRT, respectively) lower than those found at the site A; they sometimes were higher at the control stations. This distribution pattern could be due to the high hydrodynamism of this site, which was responsible of the spreading of organic matter also in areas not directly affected by the cage presence. Moreover, the reduction of PRT concentrations observed at the cage stations during the post- impact period could be related to higher decomposition mediated by $\operatorname{LAP}(\mathrm{r}=-0.95, \mathrm{P}<0.01, \mathrm{n}=4)$.

At site $\mathrm{C}$, all the microbial parameters, and particularly AP, showed higher values at the cage stations with respect to those measured at the control ones. Site $\mathrm{C}$ was characterised by the lowest CFU values. Significant increases over time were found for LAP, AP and CFU at cage stations $(\mathrm{F}=28.36, \mathrm{P}<0.01,8.07$ 
Table 1: $\quad$ Range of variation (before-after farming) of the mean values measured for each parameter in the waters and sediments of the studied sites. Water values expressed in $\mathrm{nM} \mathrm{h}^{-1}$ (LAP, $\beta$-GLU, AP),

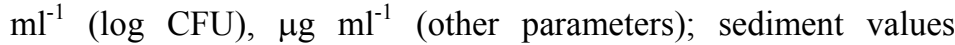
expressed in $\mu \mathrm{M} \mathrm{h}^{-1}$ (LAP, $\beta$-GLU, AP), $\mathrm{g}^{-1}$ (log CFU), $\mu \mathrm{g} \mathrm{g}^{-1}$ (other parameters).

\begin{tabular}{|c|c|c|c|c|}
\hline \multirow{2}{*}{ Parameter } & \multicolumn{2}{|c|}{ Water } & \multicolumn{2}{c|}{ Sediment } \\
\cline { 2 - 5 } & Control & Cage & Control & Cage \\
\hline LAP & $4.38-41.86$ & $4.69-806.18$ & $0.31-1.07$ & $1.02-3.03$ \\
$\beta$-GLU & $0.76-29.19$ & $0.77-32.24$ & $0.86-3.53$ & $0.68-2.75$ \\
AP & $2.20-86.78$ & $5.72-261.71$ & $1.26-21.71$ & $1.41-24.14$ \\
Log CFU & $2.38-3.34$ & $2.92-3.56$ & $3.35-4.03$ & $3.87-5.21$ \\
POM & $88.51-237.38$ & $83.17-225.63$ & $911.05-1119.77$ & $1529.63-3025.03$ \\
PRT & $38.98-115.53$ & $37.50-106.84$ & $634.94-685.86$ & $885.41-2366.99$ \\
CHO & $22.92-71.94$ & $22.34-57.57$ & $200.40-262.05$ & $453.31-482.13$ \\
LIP & $20.92-50.83$ & $19.10-61.23$ & $72.72-171.87$ & $162.10-204.74$ \\
\hline LAP & $0.15-28.97$ & $8.52-76.33$ & $0.48-12.40$ & $2.01-27.64$ \\
$\beta$-GLU & $0.42-77.46$ & $0.51-148.85$ & $0.27-4.61$ & $1.07-7.82$ \\
AP & $8.06-42.03$ & $9.54-58.30$ & $2.94-12.65$ & $10.50-145.60$ \\
Log CFU & $2.19-2.75$ & $1.98-3.13$ & $2.99-3.60$ & $2.79-4.17$ \\
POM & $69.22-103.48$ & $53.65-103.29$ & $310.13-1001.44$ & $243.61-617.45$ \\
PRT & $10.01-50.16$ & $12.32-66.29$ & $369.78-787.43$ & $84.85-369.69$ \\
CHO & $27.83-38.97$ & $18.22-34.45$ & $159.88-236.45$ & $111.50-121.11$ \\
LIP & $17.24-38.39$ & $6.89-25.54$ & $54.13-203.90$ & $37.66-136.27$ \\
\hline LAP & $2.95-99.61$ & $26.28-231.67$ & $0.11-9.30$ & $0.95-19.32$ \\
$\beta$-GLU & $5.64-13.22$ & $91.99-140.32$ & $0.77-4.30$ & $3.40-10.11$ \\
AP & $451.12-688.37$ & $950.84-2572.20$ & $14.15-35.26$ & $21.96-111.12$ \\
Log CFU & $2.49-3.44$ & $2.62-3.29$ & $3.07-3.41$ & $3.27-3.74$ \\
POM & $105.96-218.13$ & $91.93-113.90$ & 4680.38 & 5052.95 \\
PRT & $53.22-107.93$ & $47.51-65.14$ & 3335.68 & 3283.19 \\
CHO & $26.72-87.59$ & $27.04-30.19$ & 1204.45 & 1344.81 \\
LIP & $22.61-26.02$ & $17.38-18.57$ & 140.18 & 257.22 \\
\hline
\end{tabular}

and 9.94, $\mathrm{P}<0.05$, respectively); this indicated a significant impact of mariculture activities on the benthic compartment. At this site, the highest concentrations of POM and of its biopolymeric fractions were reached.

\section{Discussion}

With the onset of mariculture activity, significant variations of the enzymatic activity rates were detected at all the three sites, particularly at the cage stations. The load of both organic substrates and nutrients released by the productive practices (faecal pellets, food residuals) induced a significant enhancement of the decomposition processes of the microbial community. LAP and AP were the enzyme activities most significantly influenced by mariculture activity; this 
result probably depended on changes occurring in the metabolic profiles of the microflora caused by the change in environmental conditions. It is well known that, in aquatic environments, microbial metabolism is significantly affected by the availability and quality of organic polymers [9]. Microbial enzyme activities measured in this study fall in a range of values comparable to those reported in eutrophic areas [19, 20], showing a significant response to the presence of allochthonous inputs released by the cages. The most significant changes in the examined parameters were detected at site $\mathrm{A}$, both at pelagic and benthic compartments, and at site $\mathrm{C}$, at the benthic level.

Significant differences in the activity rates from the pre-impact to the postimpact periods were sometimes observed also at the control stations, particularly at site B, suggesting that also these stations were affected by mariculture effects, due to the high hydrodynamism. Conversely to enzyme activities, CFU remained almost homogeneous at the different sites and did not show significant variations.

The concentrations of POM found in this study were comprised in a range typical of other Mediterranean areas [21], showing in the Castellammare Gulf a seasonal variability $(\mathrm{r}=0.786, \mathrm{P}<0.05, \mathrm{n}=6$ with temperature). Compared to trophic parameters, microbial variables exhibited at all the examined sites a response more directly correlated to the presence of the disturbance factor, while organic matter did not show evident accumulation. This result could be due to the lability of organic inputs, which were quickly degraded and therefore did not cause irreversible alteration of the environmental equilibrium. Moreover, the inverse relationships found between the activity rates and POM content at the cage stations led us to hypothesise that organic inputs were quickly decomposed by enzyme activities or that the microbial community responded more to dissolved, rather than particulate, organic polymers.

The results pointed out that microbial variables can find a practical application in monitoring studies being sensitive indicators, already at an earlier phase, of changes occurring in the environment. In conclusion, the microbial variables could be proposed as a new useful tool to describe the environmental status and to monitor the interactions of productive activities on the environment, paying also attention to the pelagic compartment and not only to the benthic one.

Water parameters here presented were measured on samples taken the traditional way, with boats and sampling bottles; automatic water samplers integrated in buoy-based automatic measuring systems [22-25] or in towed ondulating vehicles [26] can give not only punctual, but time-space synoptic data to be used in complex early warning and environment monitoring networks, to better assess the mariculture impact and to help protect the capital investment from the arrival of pollutants that could damage the farmed fish or make them harmful to human health.

\section{Acknowledgement}

The authors thank Dr. A. Modica (ENI Syndial, Priolo) for the trophic data. 


\section{References}

[1] Rosenthal, H., Weston, D., Gowen, R, Black, E., Report of the ad hoc study group on "Environmental impact of Mariculture". ICES Statutory Meeting, CM, 1897/F:2, 1987.

[2] Holmer, M., Black, K., Duarte, C.M., Marbà, N., Karakassis, I. (eds). Aquaculture in the ecosystem, Springer-Verlag: New York, 2008.

[3] Danovaro, R., Corinaldesi, C., La Rosa, T., Luna, G.M., Mazzola, A., Mirto, S., Vezzulli, L., Fabiano, M., Aquaculture impact on benthic microbes and organic matter cycling in coastal Mediterranean sediments: a synthesis. Chemistry and Ecology, 19, pp. 59-65, 2003.

[4] La Rosa, T., Mirto, S., Favaloro, E., Savona, B., Sara', G., Danovaro, R., Mazzola, A., Impact on the water column biogeochemistry of a Mediterranean mussel and fish farm. Water Research, 36, pp. 251-259, 2002.

[5] Vezzulli, L., Chelossi, E., Ricciardi, G., Fabiano, M., Bacterial community structure and activity in fish farm sediments of the Ligurian Sea (Western Mediterranean). Aquaculture International, 10, pp. 123-141, 2002.

[6] Bedwell, M.S. \& Goulder, R., Bacterial outputs from ponds and tanks used in intensive fish farming. Letters Applied Microbiology, 23, pp. 412-416, 1996.

[7] Zenetos, A., Streftaris, N., Larsen, L.H., An indicator-based approach to assessing the environmental performance of European marine fisheries and aquaculture. European Environmental Agency: Copenhagen, Technical Report, 87, 2002.

[8] Danovaro, R., Gambi, C., Luna, G.M., Mirto, S., Sustainable impact of mussel farming in the Adriatic Sea (Mediterranean Sea): evidence from biochemical, microbial and meiofaunal indicators. Marine Pollution Bulletin, 49, pp. 325-333, 2004.

[9] Chrost, R. J., Microbial ectoenzymes in aquatic environments. Aquatic microbial ecology: biochemical and molecular approaches, eds. J. Overbeck \& R.J Chrost, Springer-Verlag: New York, pp. 47-78, 1990.

[10] Thompson, A.J. \& Sinsabaugh, R.L., Matric and particulate phosphatase and aminopeptidase activity in limnetic biofilms. Aquatic Microbial Ecology, 21, pp. 151- 159, 2000.

[11] Rath, J., Schiller, C., Herndl, G.J., Ectoenzymatic activity and bacterial dynamics along a trophic gradient in the Caribbean Sea. Marine Ecology Progress Series, 102, pp. 89-106, 1993.

[12] Caruso, G., Genovese, L., Mancuso, M., Modica, A., Effects of fish farming on microbial enzyme activities and densities: comparison between three Mediterranean sites. Letters Applied Microbiology, 37, pp. 324-328, 2003.

[13] La Rosa, T., Mirto, S., Mazzola, A., Danovaro, R., Differential response of benthic microbes and meiofauna to fish-farm disturbance in coastal sediments. Environmental Pollution, 112, pp. 427-434, 2001. 
[14] Hoppe, H.G., Use of fluorogenic model substrates for extracellular enzyme activity (EEA) measurement of bacteria. Handbook of Methods in Aquatic Microbial Ecology, ed. P.F. Kemp, B.F. Sherr, E.B. Sherr, \& J.J. Cole, Boca Raton: Lewis Publishers, pp. 423-431, 1993.

[15] Iseki, K., MacDonald, R.W., Carmack, E., Distribution of particulate matter in the south-eastern Beaufort Sea in late summer. Proc. of the NIPR Symposium for Polar Biology, 1, pp. 35-46, 1987.

[16] Hartree, E. F., Determination of proteins: a modification of the Lowry method that gives a linear photometric response. Analytical Biochemistry, 48, pp. 422-427, 1972.

[17] Dubois, M., Gilles, K., Hamilton, J.K., Rebers, P.A., Smith, F., Colorimetric method for determination of sugar and related substances. Analytical Chemistry, 28, pp. 350-356, 1956.

[18] Bligh, E.G. \& Dyer, W., A rapid method for total lipid extraction and purification. Canadian Journal of Biochemistry and Physiology, 37, pp. 911-917, 1959.

[19] Caruso, G. \& Zaccone, R., Estimates of leucine aminopeptidase activity in different marine and brackish environments. Journal Applied Microbiology, 89, pp. 951-959, 2000.

[20] Zaccone, R. \& Caruso, G., Microbial hydrolysis of polysaccharides and organic phosphates in the northern Adriatic Sea. Chemistry and Ecology, 18, pp. 85-94, 2002.

[21] Finenko, Z.Z. \& Zaika, V.E., Particulate organic matter and its role in the productivity of the sea. Marine Food Chains, ed. J.H. Steele, Oliver \& Boyd: Edinburgh, pp. 32-44, 1970.

[22] Zappalà, G., Caruso, G., Crisafi, E., The SAM integrated system for coastal monitoring. Proc. of the Coastal Environment IV, ed. C.A. Brebbia, WIT Press, Southampton (UK), pp. 341-350, 2002.

[23] Zappalà, G., Caruso, G., Azzaro, F., Crisafi, E., Integrated Environment Monitoring from Coastal Platforms. Proc. of MEDCOAST 03, ed. E. Ozhan, Middle East Technical University: Ankara, Turkey, 3, pp. $2007-$ 2018, 2003.

[24] Zappalà, G., Caruso G., Crisafi, E., Coastal pollution monitoring by an automatic multisampler coupled with a fluorescent antibody assay. Proc. of Coastal Environment V, eds. C.A. Brebbia, J.M., Saval Perez, L. Garcia Andion \& Y. Villacampa. WIT Press, Southampton (UK), pp. 125-133, 2004.

[25] Zappalà, G., Azzaro, F., A new generation of coastal monitoring platforms. Chemistry and Ecology, 20, pp. 387-398, 2004.

[26] Zappalà, G., Marcelli, M., Piermattei, V., Development of a sliding device for extended measurements in coastal waters. WIT Transactions on Ecology and the Environment, eds. D. Prats Rico, C.A. Brebbia, Y. Villacampa Esteve. WIT Press, Southampton (UK), 111, pp. 187-196, 2008. 